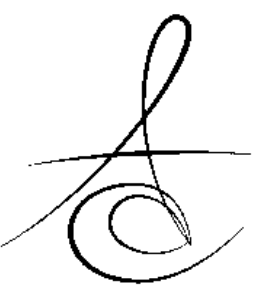

\title{
PROSTHETIC REHABILITATION OF A PATIENT WITH WORN DENTITION: A CASE REPORT*
}

\section{AŞINMIŞ DENTISYONA SAHIP HASTANIN PROTETIK REHABILITASYONU: VAKA RAPORU}

\section{Dt. Ece UÇAR*}

\section{Prof. Dr. Işıl ÇEKİÇ NAGAŞ*}

\author{
Makale Kodu/Article code: 4568 \\ Makale Gönderilme tarihi; 03.09 .2020 \\ Kabul Tarihi: 03.03.2021 \\ DOI : $10.17567 /$ ataunidfd.890549
}

Ece Uçar: ORCID ID: 0000-0002-8931-7332

Işıl Çekiç Nagaş: ORCID ID: 0000-0002-2768-7207

\begin{abstract}
Vertical height loss occurring due to parafunctional habits might cause speech, chewing and aesthetic problems. Patients often adapt to the new vertical size, in some cases the occlusal vertical size needs to be restored. A 54-year-old male patient applied to the clinic with abrasion of teeth and complaints about chewing and aesthetic. Following clinical and radiographic evaluations, appropriate vertical size for the patient was determined. Then, temporary prosthesis were fabricated and used for 2 months period. During these 2 months, the patient was checked regularly and no temporomandibular disease was observed. At the end of this period, the patient's permanent prostheses were made. In this case, there were no functional, aesthetic problems or temporomandibular disease in the periodic controls. In conclusion, when the vertical size should be increased, permanent prostheses should not be made without adapting the patient to the new vertical size.
\end{abstract}

Keywords: Attrition; occlusal vertical dimension; prosthetic rehabilitation; temporomandibular disorder; tooth wear.

\section{Öz}

Parafonksiyonel alışkanlıklar nedeniyle meydana gelen dikey boyut kaybı konuşma, çiğneme ve estetik sorunlara neden olabilir. Hastalar genellikle yeni dikey boyuta uyum sağlar, ancak bazı durumlarda oklüzal dikey boyutun restore edilmesi gerekmektedir. 54 yaşındaki erkek hasta, kliniğe dişlerde aşınma, çiğneme ve estetik şikayetler ile başvurdu. Klinik ve radyografik değerlendirmeleri takiben, hasta için uygun dikey boyut belirlendi. Daha sonra, geçici protezler hazırlandı ve 2 ay süre ile kullanıldı. 2 ay boyunca hasta düzenli olarak kontrol edildi ve herhangi bir temporomandibular hastalık gözlenmedi. Bu sürenin sonunda, hastanın daimi protezleri yapıldı. Bu vakada, yapılan periyodik kontrollerde fonksiyonel, estetik bir problem veya temporomandibular hastalık görülmemiştir. Sonuç olarak, dikey boyutun yükseltilmesi gereken durumlarda, hasta yeni dikey boyuta alışmadan kalıcı protezler yapılmamalıdır.

Anahtar Kelimeler: Atrizyon; oklüzal dikey boyut; protetik rehabilitasyon; temporomandibular bozukluk; diş aşınması.

* Gazi University, Faculty of Dentistry, Department of Prosthodontics, Ankara

¥ This study was presented at Gazi Üniversitesi Diş Hekimliği Fakültesi 1. Genç Akademisyenler Kongresi 2020, in Ankara, Turkey, on February 20-21, 2020.

Kaynakça Bilgisi: Uçar E, Çekiç Nagaş I. Aşınmış dentisyona sahip hastanın protetik rehabilitasyonu: vaka raporu. Atatürk Üniv Diş Hek Fak Derg 2021; 31: 444-8.

Citation Information: Ucar E, Cekic Naga I. Prosthetic rehabilitation of a patient with worn dentition: a case report. J Dent Fac Atatürk Uni 2021; 31: 444-48.

\section{INTRODUCTION}

Dental abrasions, which are considered as a threat to dentition, can also be caused by other factors except caries and trauma., ${ }^{1,2}$ Apart from caries and trauma, there are many reasons for enamel and dentin loss. Normal and abnormal chewing, parafunctional habits, and incorrect oral hygiene procedures are the most frequently mentioned reasons in the literature. ${ }^{1}$ Although wear caused by friction of teeth during chewing is accepted as a natural process, some factors increase the severity of wear. . $^{3,4}$

There are 4 types of dental wear called attrition, abrasion, erosion, abfraction. ${ }^{5}$ The attrition; is the loss of dental tissue that occurs when dental tissues come into contact with each other and divided into two categories as physiological and pathological. Physiological attrition occurs as a result of normal chewing. Pathological attrition is the condition when patient's wear is more than expected normal amount considering his/her age. Malpositions, malocclusions, 
parafunctional habits can cause pathological intrusion. ${ }^{6}$ Abrasion is the loss of dental tissue seen as a result of abnormal mechanical effects. It is classified according to its etiology and among many others commonly as a result of toothbrush abrasion. 5,6 Erosion is the loss of dental tissue caused by chemical reasons and there is no bacterial agent effect. There are external and internal reasons in its etiology. Food and drink consumption are considered as external causes whereas diseases such as reflux, bulimia nervosa are considered to be internal causes. Abfraction occurs as a result of occlusal forces and there is enamel loss in the cervical regions. ${ }^{5,6}$

The chewing system is a complex system consisting of teeth, bones, muscles, ligaments and temporomandibular joint (TMJ). ${ }^{7}$ Occlusal wear generally coexists with lose occlusal vertical dimension (OVD). ${ }^{8}$ TMJ, periodontal ligament and teeth may adapt to some changes in the OVD. For this reason, occlusion and OVD do not always need to be restored. However, in some serious cases, OVD may cause discomfort such as loss of aesthetics, loss of chewing function, loss of muscle tone, dentin sensitivity, pulpitis and TMJ disorders. ${ }^{3,9}$ In cases where the vertical size needs to be increased, prosthetic treatment should not be initiated immediately in order to provide the necessary time for the muscle and TMJ to adapt. Partial prostheses or occlusal splints should be used first to ensure compliance. ${ }^{6,10}$ Therefore, the reasons for wear and loss of vertical size must be correctly determined in order to perform a healthy treatment. ${ }^{3-5}$

The aim of this clinical report is to describe the rehabilitation of a patient having aesthetic and functional complaints caused by multiple tooth and vertical dimension loss by using fixed and removable prostheses in maintained occlusal vertical dimension.

\section{CASE REPORT}

A 54-year-old male patient applied to the Gazi University, Department of Prosthodontics with reduced vertical size due to multiple tooth loss in the maxillary arch and tooth abrasion in both arches (Figure 1). The patient was provided an informed consent form. In the systemic anamnesis, there wasn't any sign of systemic disorders. Additionally, in the dental anamnesis taken, it was found out that tooth loss was caused by caries and there were complaints associated with clenching at night. In the intraoral examination, it was observed that there was multiple tooth loss in the maxilla and mandible, and dentine was exposed in the incisal edges of the maxillary and mandibular anterior teeth. According to The Tooth Wear Evaluation System, the patient's occlusal and incisal abrasion was determined as grade 3 in sequences with reciprocal permanent teeth in occlusion. Non-occlusal and non-incisal abrasion were determined as grade $0 .{ }^{1}$ Upon observing the insufficient crown lengths of the anterior teeth for fixed prosthetic restoration, final decision was to perform endodontic treatment for maxillary right central incisor, maxillary left central incisor, mandibular left lateral incisor, mandibular left central incisor, mandibular right central incisor, mandibular right lateral incisor. Extraoral examination resulted in key observations including decreased lower face height, drooping and over closed commissures and wrinkles around the lips due to OVD loss. In addition, no TMJ discomfort and pain in the muscles were reported in the joint examination. In the radiological examination, it was observed that the patient had sufficient alveolar bone support in the existing teeth and no pathology was found.

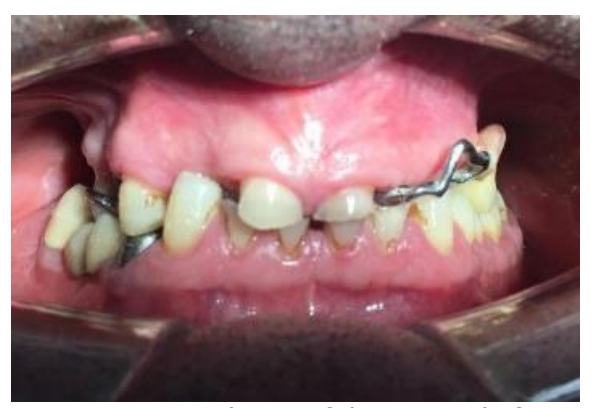

Figure 1. Intraoral view of the patient before treatment.

The patient's rest vertical dimension was determined using the Niswonger method and verified with the closest speaking space method. It was decided to increase the vertical dimension by $6 \mathrm{~mm}$. The bite was opened $6 \mathrm{~mm}$ in the anterior region to ensure proper vertical dimension and to create enough space for a prosthodontic rehabilitation. Then, a diagnostic wax-up was prepared at the determined vertical dimension. After clinical and radiological examination, intraoral images of the patient were taken, and the patient was referred to the endodontic clinic for endodontic treatments. As a result of the complication experienced after endodontic treatment, the patient's mandibular left central incisor and mandibular right central incisor teeth were extracted. 
Related area was restored with a fixed partial prosthesis afterwards.

Following the endodontic treatment, prefabricated fiber posts were placed and preparations were performed. Subsequently measurements were taken with irreversible hydrocolloid impression material (Hydrogum, Zhermack, Badia Polesine, Italy) from the upper and lower jaws. Temporary crowns were prepared with autopolymerized cold acrylic (Alike TM, GC America, Alsip, IL). At the first stage of the rehabilitation, a provisional removable restoration was fabricated at increased OVD and temporary crowns were cemented with temporary cement (Temp Bond Netm, Kerr, Salerno, Italy) (Figure 2). During the period of two months, the patient was checked regularly and no muscle tenderness or temporomandibular discomfort was observed. At the end of two months, definitive impressions of the maxillary and mandibular teeth were taken with an additional silicone impression material (Elite HD, Zhermack, Badia Polesine, Italy). After the metal and dentin rehearsal stages, definitive impressions of maxillary arc were taken with irreversible hydrocolloid impression material (Hydrogum, Zhermack, Badia Polesine, Italy). Finally, group function occlusion was achieved. Restorations were permanently cemented with polycarboxylate cement (Adhesor Carbofine, Kerr, Salerno, Italy) and an appointment was arranged for the next day to remove the removable partial denture with extracoronal ball attachments (Dental Bredent Vario Soft Ball Attachment, Senden, Germany) under control (Figure 3). After oral hygiene training, the patient was instructed about how to use the removable partial denture and 3, 6, 12 months of controls were recommended. A significant improvement in the patient's facial profile was observed at the end of the treatment (Figure 4). During routine controls, prosthesis of the patient was evaluated with a review form. There were no signs of pain and discomfort in the joint.

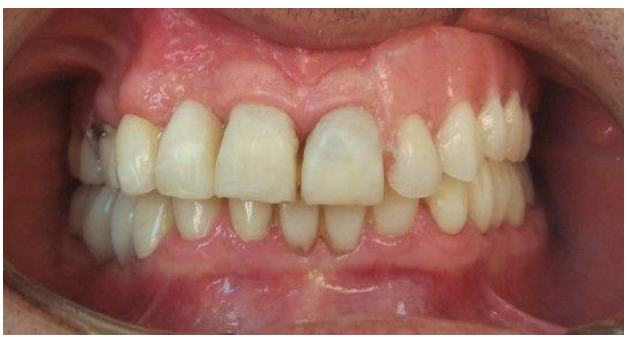

Figure 2. Intraoral view of the patient at increased vertical dimension with temporary prosthesis.

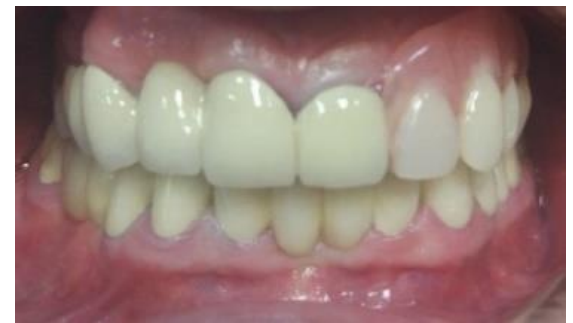

Figure 3. Post-treatment intraoral views showing restored teeth.

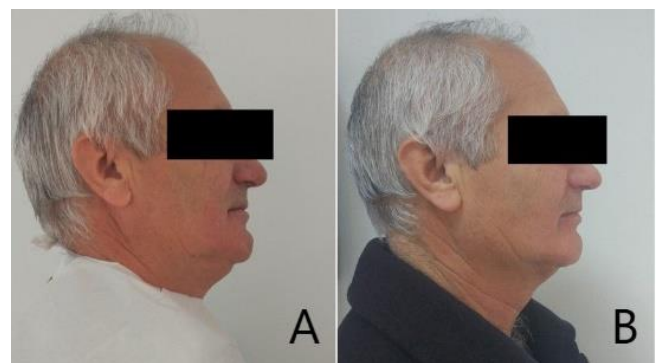

Figure 4. Post-treatment facial photographs showing the facial profile $(A)$ before treatment (B) after treatment.

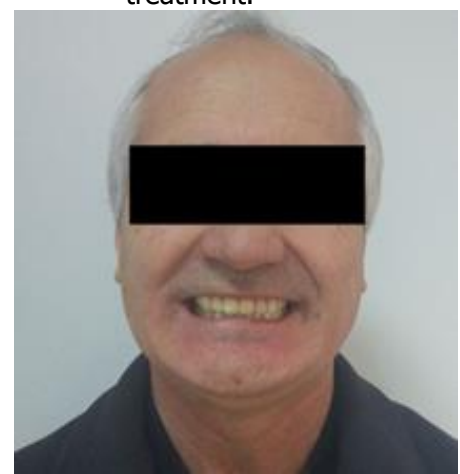

Figure 5. Post-treatment smile of the patient.

\section{DISCUSSION}

Tooth abrasions can cause problems that require treatment, such as occlusion, aesthetic and chewing problems, speech disorders and tooth sensitivity. ${ }^{11-13}$ However, tooth abrasions are not always treated. Often the occlusal vertical dimension can remain unchanged with mechanisms such as tooth riding and alveolar bone growth. ${ }^{6,14}$ It is important for physicians to communicate using various systems to decide whether it is necessary to treat dental erosion. The use of systems such as TWES 2.0 both facilitates the decision-making process of physicians and provides an objective evaluation. ${ }^{1}$

In this case, chewing function was lost due to tooth loss in the posterior, and anterior guidance was also lost due to anterior wear. Moreover, the relations between the jaws have also changed. OVD should be changed as little as possible to make it easier for the

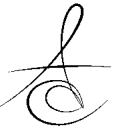


patient to adapt to the new OVD. ${ }^{9}$ In cases which OVD cannot be compensated, such as this case, occlusal splint application, temporary mobile overlay prostheses or temporary fixed restorations can be used as the first step to adapt to the new vertical dimension of the joints and muscles. In this case, we decided to make fixed temporary prostheses considering the patient's existing bridges and tooth loss in the anterior region. In order to do so, the teeth were prepared first and after making fixed temporary prostheses, a removable partial denture was prepared for the maxilla. In this case report, OVD was increased $6 \mathrm{~mm}$ in the anterior region, and 4-5 $\mathrm{mm}$ in the posterior region. Adaptation of TMJ and muscles to the new OVD requires a period of time and it depends on how much the vertical size is increased. Temporary prostheses were used for two months for the adaptation of TMJ. According to the literature, it takes 2-6 months for the patient to get used to the new OVD with temporary prostheses. ${ }^{15}$ Failures during this period such as fractures of temporary prosthesis, pulpal and periodontal problems a result of prolonged use in acrylic prostheses could be seen as a result of marginal adaptation problems in acrylic temporary prostheses. ${ }^{3,16,17}$ In addition, final prostheses must be made after adaptation to the new OVD.6,9 Overlay crowns could also be a treatment option in a patient with OVD loss. ${ }^{13}$ However, this option was not preferred for our patient since he had fixed restorations on prepared teeth. Furthermore, rehabilitation with implants could have been preferred for tooth loss in the posterior, but prostheses with removable sections were chosen for financial affordability. $^{3}$

If the clinical crown length of the existing teeth is sufficient, direct crown treatment can be considered. If the crown length is not enough, canal treatment of teeth can be considered. ${ }^{8}$ In addition, the reduced vertical size can be restored with crown lengthening or orthodontic treatments. ${ }^{3,14}$ In this case, post treatment was considered appropriate after endodontic treatment since there was too much substance loss. When it is necessary to restore natural teeth, full porcelain crowns come to the fore with their aesthetic and mechanical properties. ${ }^{18}$ However, in this case, metal supported porcelain crowns were preferred for economic reasons.

In this report, the patient firstly adapted to the temporary prostheses and the new OVD, and then a new occlusion with permanent prostheses was achieved. At the end of the treatment, both facial appearance, aesthetic and occlusion problems were resolved. Considering the profile photos at the end of the treatment and before the treatment, there is a significant change in the profile image of the patient and the height of the lower face reaches its proper position. The centric occlusion, protrusive movements, anterior guidance, and group-sparing function of the patient were checked. Since the patient's maxillary left canine tooth was not present, the function with group guidance was established. In addition, anterior guidance was especially paid attention, as it is a best practice to protect posterior teeth according to current theories. ${ }^{19}$

\section{CONCLUSION}

Restoration of the lost occlusal vertical height by prosthetic rehabilitation should be done gradually and carefully to maintain the structure and health of the chewing system. In addition, prosthetic treatment is very important for the patient's self-confidence, aesthetic appearance and chewing function.

\section{Conflict of interest}

The authors, declare that they have no conflict of interest. Funding

Neither the authors nor your institution received payment or services from a third party for any aspect of the submitted work.

\section{REFERENCES}

1. Wetselaar, Peter, et al. Diagnosing tooth wear, a new taxonomy based on the revised version of the Tooth Wear Evaluation System (TWES 2.0). J Oral Rehabil 2020;47.6:705-12.

2. Van 'T Spijker A, Kreulen CM, Creugers NHJ. Attrition, occlusion, (dys)function, and intervention: A systematic review. Clin Oral Implants Res 2007; 117-26.

3. Cekic-Nagas I, Ergun G. Implant-Supported Prosthetic Rehabilitation of a Patient with Localized Severe Attrition: A Clinical Report. J Prosthodont; 2015;24:322-8.

4. Carlsson GE, Johansson A, Lundqvist S. Occlusal wear: A follow-up study of 18 subjects with extensively worn dentitions. Acta Odontol Scand 1985;43:83-90.

5. Tunkiwala, A. The Worn and Eroded Dentition: Etiology, Risk Assessment, \& Treatment Considerations. J Cosmetic Dent 2020;36.1:50-66. 
6. Tosun B, Yanıkoğlu N. Dikey Boyut Kaybi Olan Bir Hastanin Protetik Tedavisi: Vaka Sunumu. Atatürk Üniv Diş Hek Fak Derg 2018;29.2:326-31.

7. Yadav S. A study on prevalence of dental attrition and its relation to factors of age, gender and to the signs of TMJ dysfunction. J Indian Prosthodont Soc 2011;11:98-105.

8. Turner KA, Missirlian DM. Restoration of the extremely worn dentition. J Prosthet Dent 1984;52:467-74.

9. Cura C, Saraçoğlu A, Öztürk B. Prosthetic rehabilitation of extremely worn dentitions: Case reports. Quintessence Int (Berl) 2002;33:225-230.

10. Conti Paulo César Rodrigues, et al. The treatment of painful temporomandibular joint clicking with oral splints: a randomized clinical trial. J Am Dent Assoc 2006;137.8: 1108-14.

11. Smith BGN, Bartlett DW, Robb ND. The prevalence, etiology and management of tooth wear in the United Kingdom. J Prosthet Dent 1997;78:367-72.

12. Ergun G, Cekic-Nagas I. Implant-prosthetic rehabilitation of a patient with nonsyndromic oligodontia: A clinical report. J Oral Implantol 2012;38:497-503.

13. Windchy AM, Morris JC. An alternative treatment with the overlay removable partial denture: a clinical report. J Prosthet Dent 1998;79:249-253.

14. Chu FCS, Siu ASC, Newsome PRH, Chow TW, Smales RJ. Restorative management of the worn dentition: 4. Generalized toothwear. Dent Update 2002;29:318-24.

15. Song MY, Park JM, Park EJ. Full mouth rehabilitation of the patient with severely worn dentition: A case report. J Adv Prosthodont 2010;2:106-10.

16. Verri FR, Pellizzer EP, Mazaro JVQ, De Almeida EO, Antenucci RMF. Esthetic interim acrylic resin prosthesis reinforced with metal casting. J Prosthodont 2009;18:541-4.

17. Burns DR, Beck DA, Nelson SK. A review of selected dental literature on contemporary provisional fixed prosthodontic treatment: Report of the Committee on Research in Fixed Prosthodontics of the Academy of Fixed Prosthodontics. J Prosthet Dent 2003;90:474-97.

18. Barão, Valentim Adelino Ricardo et al. Factors to achieve aesthetics in all-ceramic restorations. J Craniofacial Surg 216 2007-2012
19. Abduo J, Lyons K. Clinical considerations for increasing occlusal vertical dimension: A review. Aust Dent ] 2012;57:2-10.

\author{
Sorumlu Yazarın Yazışma Adresi \\ Dt. Ece Uçar \\ Gazi Üniversitesi Diş Hekimliği Fakültesi \\ Protetik Diş Tedavisi ABD \\ Ankara, Türkiye \\ Tel: 03122034175 \\ Faks: 03122239226 \\ E-mail: ece.ucar@gazi.edu.tr
}

